\title{
Spatial Distribution of Trace Elements in Rice Field at Prafi District Manokwari
}

\author{
Aplena Elen S. Bless., Yahya Darmawan and Samen Baan \\ Received: 26112015 / Accepted: 1901 2016 / Published online: 30062016 \\ (C) 2016 Faculty of Geography UGM and The Indonesian Geographers Association
}

\begin{abstract}
Mapping spatial variability of trace elements in rice field is necessary to obtain soil quality information to enhance rice production. This study was aimed to measure concentration and distribution of $\mathrm{Zn}, \mathrm{Cu}, \mathrm{Fe}, \mathrm{Pb}$, and $\mathrm{Cd}$ in two different sites (SP1, SP2) of Prafi rice field in Manokwari West Papua. The representative 26 soil samples were analysed for their available trace metal concentration (DTPA), soil pH, and C-organic and soil texture. The result indicated that Fe toxicity and $\mathrm{Zn}$ deficient problems were encountered in both sites. Rice field in SP2 was more deficient in $\mathrm{Zn}$ than SP1. Site with the highest trace elements $(\mathrm{Zn}, \mathrm{Fe}, \mathrm{Cu}$, and $\mathrm{Cd}$ ) concentration had low soil pH and high C-organic. Acidic soil has higher solubility of metals; while high C-organic could improve the formation of dissolve organic carbon-metal binding, hence it improving the trace metals concentration in soil solution.
\end{abstract}

Keywords: Spatial distribution, Prafi, Rice field, Trace elements, Iron, Zinc

\begin{abstract}
Abstrak Pemetaan keragaman spasial dari logam berat pada lahan sawah sangat perlu dilakukan, guna mengetahuhi kualitas tanah sehingga usaha peningkatan produksi padi dapat dilakukan. Penelitian ini bertujuan untuk mengetahui kosentrasi dan distribusi $\mathrm{Zn}, \mathrm{Cu}, \mathrm{Fe}, \mathrm{Pb}$, dan $\mathrm{Cd}$ pada dua lokasi (SP1,SP2) lahan sawah di Prafi. Ada 13 sampling plot dengan dua tingkat kedalaman, sehingga total diperoleh 26 sampel tanah. Analisis tanah yang dilakukan adalah konsentrasi dari logam berat (DTPA), $\mathrm{pH}$ tanah, Corganik, dan tekstur tanah. Hasil penelitian menunjukan bahwa kedua daerah penelitian mengalami masalah keracunan Fe dan kekurangan Zn. Lahan sawah di SP1 lebih kekurangan Zn dibandingkan lahan SP2. Lahan yang memiliki kosentrasi logam berat ( $\mathrm{Zn}, \mathrm{Fe}, \mathrm{Cu}, \mathrm{Cd})$ paling tinggi memiliki $\mathrm{pH}$ tanah yang rendah dan $C$-organic tanah yang tinggi. Tanah dengan kondisi masam memiliki kelarutan logam berat yang tinggi, sedangkan kandungan Carbon yang tinggi dapat memicu pembentukan ikatan organic carbon-metal yang dapat larut sehingga menigkatkan ketersediaan logam berat pada larutan tanah.
\end{abstract}

Kata kunci: Distribusi spasial, Prafi, Padi sawah, Unsur mikro, Besi, Seng

\section{Introduction}

Geostatistical application is widely used in soil science, since geo-statistics offers tools that enable to describe the spatial pattern of soil characteristics. By using geo-statistics, it is possible to assess uncertainty of non-sampled data, and provides map that describes probability of exceeding critical values, such as criteria of soil pollution or soil quality [Goovaerts, 1998]. Several soil variability assessments in order to improve agricultural productivity and sustainable farming design have been done. In Southeast China, Zhao et al. [2010] created soil distribution maps that were mainly characterized by soil chemical properties and found that soil $\mathrm{pH}$, available $\mathrm{K}$ and $\mathrm{Si}$ had similar spatial distribution pattern where the high level is distributed in Southwest China and low level is distributed in

Aplena Elen S. Bless and Samen Baan

Soil Science Department, Agricultural Faculty, Papua University, Papua Barat, Indonesia.

Email: elen_blss@yahoo.com

Yahya Darmawan

Indonesian Agency for Meteorological, Climatological and Geophysics (BMKG) Region I
Southeast China, so the recommended fertilization balanced based on the regional distribution maps. Another researched [Ruth and Lenartz, 2008] on soil properties and soil landscape using geostatistical analysis suggested that relief position substantially influenced spatial distribution of soil texture, total carbon and total nitrogen contents in the terrace paddy landscape. This finding proposed that management on site specific area of sandy soil texture could enhance the production of rice. Soil properties mainly regulate both macro and micro (trace elements) nutrients availability, which can be statistically and geostatistically evaluated.

Bioavailability and uptake rate of trace elements such as Zinc $(\mathrm{Zn})$, Copper $(\mathrm{Cu})$, Iron $(\mathrm{Fe})$, Cadmium $(\mathrm{Cd})$ and Lead $(\mathrm{Pb})$ are determined by its solubility rate. Furthermore, chemical processes like reduction and oxidation (redox) conditions also influence the availability of the trace elements to the plant, especially on rice field. Pan et al. [2015] suggested that redox potential (Eh), soil $\mathrm{pH}$ and dissolve organic carbon strongly affected the solubility of trace metals. They made a prediction using multi surface modelling and found that under high soil $\mathrm{pH}$, the solubility was lowering the oxidation (dry soil) condition, resulting 
in a low concentration of trace metals due to complex formation of the metals with reactive soil surface. While under reduction condition (anaerobe), metals desorption were governed by formation of sulphide precipitation; and the trace metal concentrations were predicted to be high at acidic soil [Zachara et al., 1992].

The addition of trace metals to agricultural field came from different anthropogenic pathways, such as; transported suspension from irrigation water [Simmons, et al., 2005], smoke of vehicles [Romic, 2003], the usage of pesticide and fertilizer that contain trace metals [Zarcinas et al., 2004], and also from atmospheric deposition through the rain. Though, some soils types have already contain trace metals, the concentrations are generally low. Metal contamination on rice fields occurred in several Asian countries such as Thailand, China, Japan, Korea, including Indonesia [Wei and Chen, 2001; Jo and Koh, 2004; Kurnia et al 2005], where rice is the main staple food.

In order to maintain the food security, particularly improving rice production in Indonesia, the Government executed a project called Transmigration. This project had been started in around 1950's, new agricultural fields (rice field, crops, and vegetables) in new regions with less population density such as Sumatra, Kalimantan and Papua. Prafi District located in Manokwari, West Papua Province, is one of the transmigration areas started in 1981. Today, there are about 842 ha of rice fields in Prafi (SP1 and SP2), which were provided by the government to the transmigrated people from Java Island. The cultivation of rice was started in 1990s together with reconstruction of irrigation dam. Rice productivity in Manokwari is still below ( 4.3 ton/ha) the national target which are 5.3 ton/ ha (Kementrian Pertanian Republik Indonesia, 2015). Many researches, including fertilizer application to enhance the rice production had been done. However, these studies from Noya et al, [2009], Aminudin, [2011]; and Hiddayati, [2013] about rice field in Manokwari were mostly focus on macro nutrients (NPK) and less on trace elements which are also important to rice productivity. For example, $\mathrm{Fe}$ and $\mathrm{Zn}$ is one of trace elements essential for rice growth and human health. The objective of this study was to measure concentration and distribution of some trace elements $(\mathrm{Zn}, \mathrm{Cu}, \mathrm{Fe}, \mathrm{Pb}$, $\mathrm{Cd}$ ) and their relationship to soil properties in rice field in Prafi.

\section{The Methods}

Prafi district is known as one of the rice production centre in Manokwari, West Papua Province. The area is consisted of two productive unit locations, SP1 (431 ha) and SP2 (411 ha). They have three growth seasons (February, June, October) and the rice productivity was around 4.3 ton/ha in 2013 [Dinas Pertanian Kabupaten Manokwari, 2014]. The area is an alluvium plain with Inceptisol soil type, and the altitude is about $300 \mathrm{~m}$ from mean sea level.

\section{Soil Samples}

Soil sampling was performed in two different depths, top soil $(0-15 \mathrm{~cm})$ and sub soil $(15-30 \mathrm{~cm})$ because it was assumed that concentration of trace elements are high at these depths. There were 13 sampling points and 26 soil samples which were randomly sampled and presumed as representative sample of rice field. However, the chosen points were selected based on their distance from the main road, to minimize the metals addition from smoke of vehicle. The sampling activity was done in 5 days in April 2015 at various age of paddy growth stage, between 20 days to 70 days, since the farmers did not start planting at the same time. The coordinate points were taken on each soil sample sites. For preparation, soils samples were taken to laboratory of Soil Science Department at Papua University. Soils were air drying for about 4-6 days to remove the water, then sieved on 10 mesh $(2.5 \mathrm{~cm})$ screening. Afterwards the samples were sent to soil laboratory of IPB Bogor for further analysis. Trace metals $(\mathrm{Zn}, \mathrm{Cu}, \mathrm{Fe}, \mathrm{Pb}, \mathrm{Cd})$ concentration in soil solution were analyzed using DTPA extraction method [BPPT, 2009]. Others soil properties such as soil organic carbon that measured total carbon by wet oxidation using sulphate acid and potassium dichromate (Walkey and Black), soil $\mathrm{pH}$ $\left(\mathrm{H}_{2} \mathrm{O}, 1: 1\right)$ and soil texture (hydrometer) were analysed as well.

\section{Statistical and Geostatistical Analysis}

Regression analysis was applied to see statistical relation between soil characteristics (soil pH, Carbon content and soil structure) and the availability of trace metals concentration in soil solution. Geostatistical analysis measured spatial distribution of metal elements in rice field in Prafi. It used interpolation method of Inverse Distance weight (IDW) using ArcGIS 10.2. IDW method was applicable to this research because the points were relative closed to each other and had similar elevation [Pasaribu and Haryani, 2012]. Inverse distance weighted (IDW) interpolation explicitly implements the assumption that things that are close to one another are more alike than those that are farther apart [ESRI, 2016]. To predict a value for any unmeasured location, IDW uses the measured values surrounding the predicted location. The measured values closest to the predicted location have more influence on the predicted value than those further away. IDW assumes that each measured point has a local influence that diminishes with distance. It gives greater weights to points closest to the prediction location, and the weights diminish as a function of distance, hence the name inverse distance weighted.

IDW is an exact interpolator, where the maximum and minimum values in the interpolated surface can only occur at sample points. The output surface is sensitive to clustering and the presence of outliers. IDW assumes that the phenomenon being modeled is driven by local variation, which can be captured (modeled) by 
defining an adequate search neighborhood. Since IDW does not provide prediction standard errors, justifying the use of this model may be problematic [ESRI, 2016].

Comparing to another interpolation method such as kriging, IDW does not produce the prediction standard errors. However, Pasaribu and Haryani [2012] found that IDW has a good prediction value when the measurement points located by a short distance and has relatively similar elevation. In this research, most of the points are separated by a short distance (maximum distance is about $1 \mathrm{~km}$ ) and the study area has a flat elevation. Furthermore, IDW is known as the fastest interpolation method which is producing the smooth of interpolation results [ESRI, 2016]. Due to those considerations, we decided to use IDW and does not perform the accuracy assessment.

In this research, we used ArcGIS 10.2. ArcGIS 10.2 has a spatial analyst tool which can give us some options for interpolation methods. For performing IDW, there were some steps which had to do. First, we have to determine the threshold (criteria) for every soil's parameters. The criteria for classifying the trace metals will be defined based on BPPT [2009]. For every trace metals, the criteria has defined and it can be seen on Table 1. Second, we have to show the points's location and plot the points. Third, we had initiate the IDW interpolator using IDW toolbar in ArcGIS 10.2 (Spatial Analyst Tools $\rightarrow$ Interpolation $\rightarrow$ IDW). In this research, we used distance squared using the 13 of the nearest points. We also retained the default grid size (9.2 meters). Fourth, we performed the reclassification of IDW's result based on trace metals's criteria in the previous step and showed in the map.

\section{Results and Discussion \\ Soil Properties}

The soil $\mathrm{pH}$ of rice field in Prafi ranged from $\mathrm{pH}$ of 5.4 to 7.2 , which can be categorized as medium acid to neutral soil. The average soil pH in SP1 is slightly higher compared to SP2. The average of Carbon (C) in SP2 is two times greater than SP1. The C-organic in SP2 was mostly categorized as medium, whereas the C-organic

Table 1. Trace Metals Concentration in Soils

\begin{tabular}{|c|c|c|c|}
\hline Trace Metals $\backslash$ Category & Normal (ppm) & Critical (ppm) & \\
\hline $\mathrm{Cd}$ & 0.01 & 8-Mar & \\
\hline \multirow[t]{2}{*}{$\mathrm{Pb}$} & $2-300$ & $100-400$ & \\
\hline & Deficient (ppm) & Sufficient (ppm) & Toxic (ppm) \\
\hline $\mathrm{Zn}$ & $0.5-1$ & $>1$ & $>70$ \\
\hline $\mathrm{Cu}$ & $<0.2$ & $>0.2$ & $>60$ \\
\hline $\mathrm{Fe}$ & $2.5-4.5$ & $>4.5$ & $>100$ \\
\hline
\end{tabular}

Source: BPPT [2009].

Table 2. Soil Analysis (0-15cm) of Rice Paddy Field in Prafi District, Manokwari West Papua Province

\begin{tabular}{lrrrrrrrrrrr}
\hline Location & pH & C (\%) & $\begin{array}{c}\text { Clay } \\
(\%)\end{array}$ & $\begin{array}{c}\text { Silt } \\
(\%)\end{array}$ & $\begin{array}{c}\text { Sand } \\
(\%)\end{array}$ & Texture Class & $\begin{array}{c}\text { Zn } \\
(\mathrm{ppm})\end{array}$ & $\begin{array}{c}\mathrm{Fe} \\
(\mathrm{ppm})\end{array}$ & $\begin{array}{c}\mathrm{Cu} \\
(\mathrm{ppm})\end{array}$ & $\begin{array}{c}\mathrm{Cd} \\
(\mathrm{ppm})\end{array}$ & $\begin{array}{c}\mathrm{Pb} \\
(\mathrm{ppm})\end{array}$ \\
\hline SP1.1 & 7.2 & 0.84 & 4.19 & 59.71 & 36.1 & Silt Loam & 1.44 & 293.5 & 2.55 & 0.03 & 0.07 \\
SP1.3 & 5.4 & 1.61 & 16.58 & 53.94 & 29.48 & Silt Loam & 0.74 & 10.33 & 1.12 & 0.04 & 0.22 \\
SP1.4 & 7.2 & 0.38 & 1.27 & 66.7 & 32.03 & Silt Loam & 1.6 & 147.48 & 2.35 & 0.04 & 0.28 \\
SP1.5 & 6.2 & 1.23 & 2.36 & 64.12 & 33.52 & Silt Loam & 1.25 & 4.74 & 1.56 & 0.05 & 0.06 \\
SP2.1 & 6.4 & 0.46 & 1.23 & 59.66 & 39.11 & Silt Loam & 1.3 & 23.45 & 2.51 & 0.04 & 0.19 \\
SP2.2 & 5.9 & 2.3 & 2.67 & 65.85 & 31.48 & Silt Loam & 1.24 & 17.41 & 1.21 & 0.07 & 0.25 \\
SP2.3 & 6 & 1.3 & 1.36 & 54.59 & 44.05 & Silt Loam & 0.56 & 34.92 & 2.53 & TR & 3.06 \\
SP2.4 & 5.7 & 1.84 & 3.86 & 62.46 & 33.68 & Silt Loam & 0.68 & 88.8 & 3.25 & TR & 3.13 \\
SP2.5 & 5.7 & 2.07 & 1.22 & 61.34 & 37.44 & Silt Loam & 0.72 & 49.52 & 1.7 & 0.05 & 1.62 \\
SP2.6 & 5.8 & 2.69 & 4.85 & 39.94 & 55.21 & Sandy Loam & 0.69 & 58.71 & 1.88 & 0.05 & 1.01 \\
SP2.7 & 5.3 & 2.92 & 5.71 & 59.6 & 34.69 & Silt Loam & 0.71 & 188.7 & 3.4 & 0.07 & 1.04 \\
SP2.8 & 5.5 & 1.15 & 5.62 & 47.29 & 47.09 & Loam & 6.76 & 54.67 & 1.46 & 0.04 & 1.09 \\
SP2.9 & 5.7 & 1.46 & 3.14 & 17.96 & 78.9 & Sandy Loam & 0.99 & 30.18 & 0.9 & 0.02 & 0.82 \\
\hline
\end{tabular}

Source: Soil Analysis of IPB Soil Laboratory, 2015; TR: undetected 

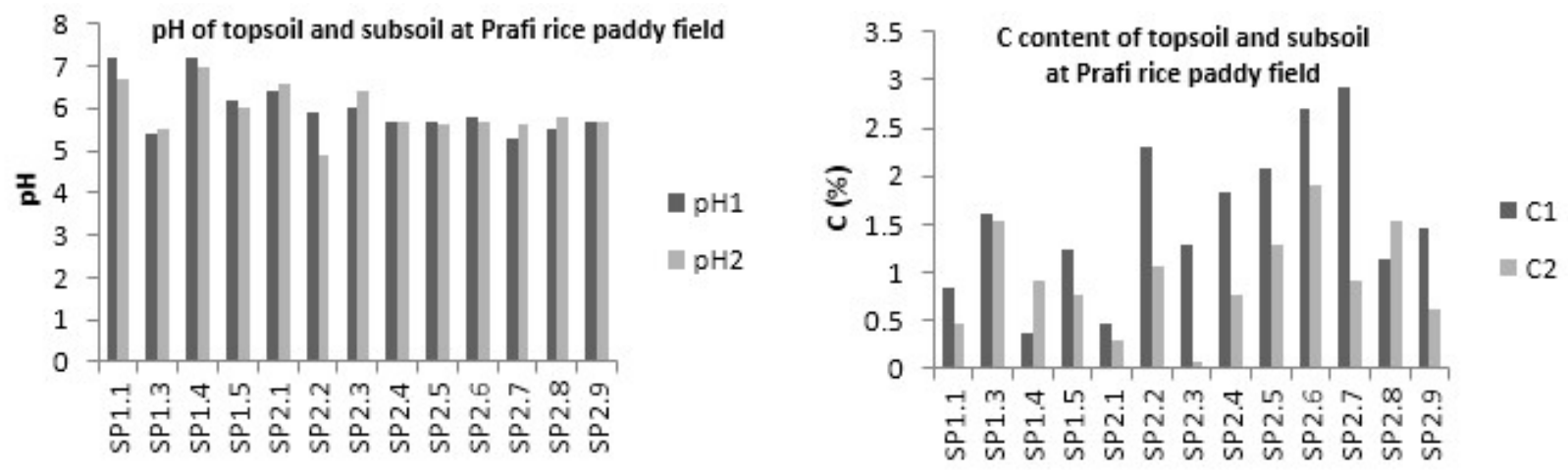

Figure 1. Soil Carbon and $\mathrm{pH}$ under of rice paddy field at Prafi District.

(C1 : topsoil carbon, $\mathrm{C} 2$ : subsoil carbon, $\mathrm{pH} 1$ :topsoil $\mathrm{pH}, \mathrm{pH} 2$ : subsoil $\mathrm{pH}$ )
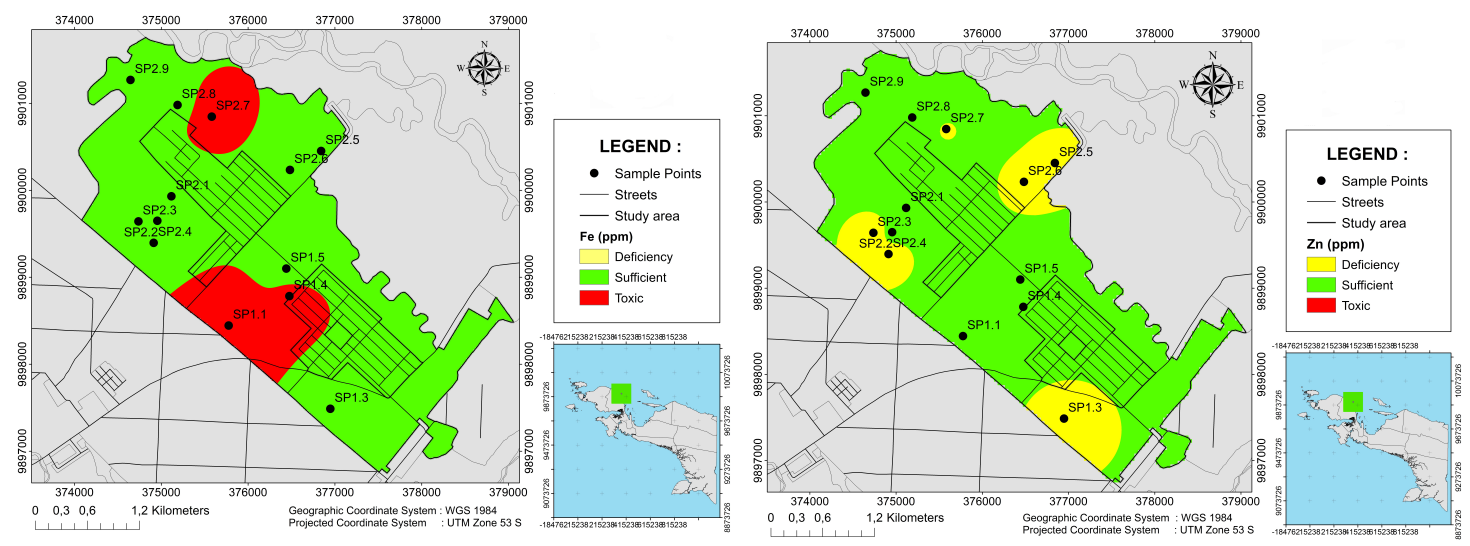

Figure 2. Spatial distribution of trace elements $(\mathrm{Fe}, \mathrm{Zn}, \mathrm{Cu}, \mathrm{Pb})$ in rice paddy field in Prafi, Manokwari.

was low in SP1. Therefore, it can be said that the soil organic material in this area was still low. Overall, soil texture in the rice field was rich $(>50 \%)$ in silt content and the texture class was silt loam, except in the two locations at SP2 that had more sand particles, so the texture was sandy loam (Table 2). The increase of soil depth $(15-30 \mathrm{~cm})$ reduced the C-Organic, but the soil $\mathrm{pH}$ and texture are similar (figure 3 ).

\section{Trace metals distribution.}

The distribution of each trace element in rice field in Prafi is provided in Figure 4. The concentration of Fe (Table 2) in the DTPA extraction exceeded the standard concentration (Table 1) of Fe soil that provided by Indonesia Soil Research Centre Bogor [BPPT, 2009]. Two sampling plots of SP1.1 and SP2.7 had a very high content of Fe range from 147-293 ppm. This value might cause toxicity for rice growth. In contrast, the $\mathrm{Zn}$ concentrations were deficient $(<1 \mathrm{ppm})$ in both fields. These concentrations were undesirable for rice productivity. Others trace metals $\mathrm{Cu}, \mathrm{Zn}$ and $\mathrm{Pb}$ were in normal and sufficient concentration based on the aforementioned standard. Mostly, $\mathrm{Cu}$ concentrations were range from 0.9-2.4 ppm which was sufficient for plant growth. At the same time $\mathrm{Pb}$ and $\mathrm{Cd}$ concentration were also below the critical value.

Trace metals distribution depend on their mineral solubility that influenced by several soil properties such as soil $\mathrm{pH}$, soil organic content, and changing redox condition particularly for rice field. During the anaerobic situation, soil $\mathrm{pH}$ increase and leads to high adsorption of trace metals that resulted in low concentration of trace metals $(\mathrm{Zn}, \mathrm{Fe}, \mathrm{Cu}, \mathrm{Cd}, \mathrm{Pb}$ ) in soil solution [Du Laing et al, 2008]. The soils were sampled under dry field condition, so they experienced aerobe condition. The result showed that the highest concentration of $\mathrm{Zn}(6.76 \mathrm{ppm}), \mathrm{Cu}(3.40 \mathrm{ppm})$ and $\mathrm{Cd}(0.07 \mathrm{ppm})$ occurred at acidic soils with pH 5.5 and pH 5.3 respectively. This finding was in agreement with Pan et al, [2015], where under acidic soil condition, concentration of trace metals raised due to the high solubility of mineral; meanwhile at high soil $\mathrm{pH}$, the 
concentrations were low due to presence of carbonate material that strongly bind trace elements. Furthermore, soil organic matter (SOM) content also influences the concentration of trace metals in soil because it provides surface for trace metals adsorption, complexation or chelation. Adsorption is attachment of metal ions on the surface of organic substrate, while complexation means a strong binding of metal ions with organic substrate to form a new complex compound; and chelation means ion metals is coated by organic compound. In this sense the high organic content will reduce the solubility of metals; whereas dissolved organic carbon forms soluble metal complexes [Alvim Ferraz and Lourenço, 2000], so it would enhance the concentration of trace metals in soil solution. Therefore, SOM can either increase or decrease the availability of trace elements in soil. Our result showed that concentrations of $\mathrm{Cu}$ and $\mathrm{Cd}$ were high at the highest SOM content (5\%). At this condition, dissolve organic carbon might be high and increases the formation of soluble metal complexes of $\mathrm{Cu}$ and $\mathrm{Cd}$. The statistical analysis of current result showed a correlation between soil C-organic with $\mathrm{Cd}$ $(\mathrm{R} 2=0.43)$.

\section{Iron toxicity and Zinc deficiency}

Iron toxicity may occur in different soil types since most of soil minerals are rich in iron (Fe). The Fe toxicity in rice field is indicated by great concentration of reducible iron $(\mathrm{Fe} 2+)$ in soil. The low soil $\mathrm{pH}$ and low cation exchange capacity (CEC) induce Fe toxicity. The Fe toxicity often occurred with $\mathrm{P}$ and $\mathrm{Zn}$ deficiency [Kirk, 2004]. The high amount of iron (100-1000 ppm) in soil leading to iron toxicity, even in some location with sandy valley bottom soil like in Guinea and Madagascar, the threshold of iron toxicity even lower (20-600 ppm) [Becker and Asch, 2005]. Soils with high sand particles are susceptible to iron toxicity compared to clay. The current finding, showed that almost all of sampling sites had Fe concentration up to $20 \mathrm{ppm}$ and this soil were dominant with sandy particles (29-78\%); therefore rice field in Prafi had indication of iron toxicity problem. Some rice plants in site SP1.1 revealed yellow leaf and lower plant height during their growing stage. The general symptom of Fe toxicity in plant is bronzing. Thus, further investigation of Fe concentration in plant tissues and roots is demanded.

As previously stated, those areas with Fe toxicity tend to suffer $\mathrm{Zn}$ deficiency (Figure 4). This might be caused by strong binding of Fe oxides with $\mathrm{Zn}$. In addition, formation of re-oxidised iron around rice rhizosphere may form soluble $\mathrm{ZnFeSO} 4$ and thus resulted in less soluble $\mathrm{Zn}$ (Sajwan and Lindasy, 1988). This is related with our result that some sites that faced Fe toxicity, particularly SP2.7, presented low Zn concentration in soil and categorized as Zn deficiency. Furthermore, some plants like rice (Oriza sativa), white lupin (Lupinus albus L.) and rapeseed (Brassica napus L.) exudate low molecular organic acid such us malate or citrate under $\mathrm{Zn}$ and $\mathrm{P}$ deficiency, in order to increase bioavailability of those nutrients [Gao, 2009; Hoffland, 2006; Bless, 2012]. This low molecular organic acid might enhance microbial reduction of iron, and could form dissolve organic complexion with iron resulted in high concentration of Fe in soil solution.

Agronomic intervention strategies such as the use of adapted rice cultivars that are tolerant to iron toxicity would be one of ways in order to resolve iron toxicity problem. Some rice varieties such as Kapuas, Batang Ombilin, Cisanggarung and Mekongga are known as tolerant to Fe toxicity [Syafruddin et al, 2008]. Furthermore, it is important to do further analysis of Fe concentration in plant tissue and its correlation with the rice production. Whereas, the application of Zinc fertilizer (EDTA Seng, Zinc Sulphate) in the rice field, is one of the strategies for $\mathrm{Zn}$ deficiency because Prafi rice field were mostly fertilized with Urea and Phonska Fertilizers.

\section{Conclusion}

The distribution of trace elements; $\mathrm{Zn}, \mathrm{Fe}, \mathrm{Cu}, \mathrm{Pb}$ and $\mathrm{Cd}$ at rice field in Prafi were spatially different between SP1 and SP2. Zinc concentration was mostly deficient in SP2 than SP1 site. Meanwhile, both areas experience iron toxicity problem. The highest concentration of Fe is found in SP1.1 (298 ppm) and SP2.7 (188 ppm). The others trace metals $(\mathrm{Cu}, \mathrm{Pb}$ and $\mathrm{Cd}$ ) were not under critical range concentration for the plant growth. Sites of SP2.7 and SP2.8 that showed high $\mathrm{Zn}, \mathrm{Fe}, \mathrm{Cu}, \mathrm{Cd}$ concentrations, had low soil $\mathrm{pH}$ and high organic matter content. The introduction of tolerant rice varieties of iron toxicity and application of $\mathrm{Zn}$ fertilizer would be the proper agronomic intervention in order to address this circumstance. In addition, it is recommended to conduct further investigation on $\mathrm{Zn}$ and $\mathrm{Fe}$ concentration on rice plant tissue under different stages of plant growth, to see assess the metal absorption in plant tissue.

\section{Acknowledgement}

The Directorate of Higher Education, Indonesia Higher Education Ministry is highly acknowledged for financing the Fundamental research scheme of Hibah Bersaing 2014-2015 period.

\section{Reference}

Alvim Ferraz, M.C.M., \& Lourenço, J.C.N., (2000). The influence of organic matter content of contaminated soils on leaching rate of heavy metals. Environmental Progress and Sustainable Energy. 19(1), 53-8.

Aminudin (2011). Upaya peningkatan produksi padi sawah di Kampung Udapi Hilir Distrik Prafi Kabupaten Manokwari. Journal Penyuluhan Pertanian. 6(1), 212-220. (in bahasa indonesia)

Balai Penelitian Tanah (2009). Petunjuk teknis 
analisis kimia tanah, tanaman, air dan pupuk, Badan Penelitian dan Pengembangan Pertanian Depertemen Pertanian.(in bahasa indonesia)

Becker M. \& Asch F., (2005). Iron toxicity in rice-Conditions and management concepts. Journal of Plant Nutrition and Soil Science. 168(4), 558-573.

Bless A.E.S., (2012). Citrate root exudation under $\mathrm{Zn}$ and P Deficiency. Journal of Tropical Soil. 17(3), 219-225.

Du Laing G., Rinklebe J., Vandecasteele B., Meers E. ,\& Tack F. M. G. (2008). Trace metal behaviour in estuarine and riverine floodplain soils and sediments: A review, Science of the Total Environment 407 (2009),3972-3985

Gao XP, F Zhang \& Hoffland E. (2009). Malate exudation by six aerob rice genotypes varying in zinc uptake efficiency. J. Environ Qual. 38(6), 2315-2321.

Goovaerts P. (1998). Geostatistic in soil science: stateof-the-art and perspectives. Geoderma. 89(1-2), $1-45$.

Hiddayati D. (2013). Kesuburan tanah sawah di Kampung Sidey Baru Manokwari. Skripsi. Universitas Negeri Papua. Manokwari.(in bahasa indonesia)

Hoffland, E., Wei, C.Z. \& Wissuwa, M. (2006). Organic anion exudation by lowland rice (Oryza sativa L.) at zinch and phosphorus deficiency. Plant soil 283(1), 155-165.

Jo I. S \& Koh M. H., (2004). Chemical change in agricultural soils of Korea: date review and suggested countermeasures. Environmental Geochemistry and Health. 26(2004), 105-107.

Kementrian Pertanian Republik Indonesia (2015). Basis data pertanian (data file), retrieved from http://aplikasi.pertanian.go.id/bdsp/hasil_lok.asp. (in bahasa indonesia)

Kirk G. J. D., (2004). The biogeochemistry of submerged soils. John Willey and Sons.Chichester,.UK.

Kurnia U., Suganda H., Saraswati R. \& Nurjaya (2005). Teknologi pengendalian pencencemaran lahan sawah dan Teknologi Pengelolaannya. pg 249-283. Jakarta.

Noya A.I, Djuuna I.A.F., \& Bachri S., 2009, Pemanfaatan pupuk biologi sebagai alternative pengganti pupuk N dan P di Distrik Masni Kabupaten Manokwari Papua Barat, Universitas Negeri Papua, Manokwari.

Pan Y., Bonten L.T.C., Koopmans G.F., Song J., Luo Y., Temminghoff E.J.M., Comans R.N.J., (2015). Solubility of trace metals in two contaminated paddy soils exposed to alternating flooding and drainage. Goderma. 261(2015),59-69.

Romic, M. (2003). Heavy metal distribution in agricultural topsoil in urban area. Environmental Geology . 43:795-805.

Ruth B. \& Lennartz B., (2008). Spatial variability of soil properties and rice yield along two catenas in southeast China. Pedospehere. 18(4), 409-420.

Sajwan K. S., \& Lindsay W. L., (1998). Effect of redox on zinc deficiency in paddy rice. Soil Sci Soc. Am. J. 50(5), 1264-1269.

Simmons R.W., Pongsakul P., Saiyasitpanich D., \& Klinphoklap S., (2005). Elevated levels of cadmium and zinc in paddy soils and elevated levels of cadmium in rice grain downstream of a zinc mineralized area in Thailand: Implication for public health. Environ. Geochem. Health. 27(5), 501-511.

Syafruddin, J. Langsa \& Saidah (2008). Hasil kegiatan program prima tani di Kabupaten Tolitoli. Lokakarya laporan kemajuan kegiatan prima tani wilayah Sulawesi dan Maluku di Kendari, April 2008.(in Bahasa Indonesia)

Wei C.Y., \& Chen T.B., (2001). Hyper accumulators and phytoremediation of heavy metal contaminated soil: a review of studies in China and abroad. Acta Ecologica Sinica. 21 (7)1196-1203.

Zachara J.M., Smith S.C., Resch C.T., \& Cowan C.E., (1992). Cadmium sorption on silicates and oxides. Soil Sci. Soc. Am. Journal. 56(4). 1074- 1084.

Zarcinas B.A., Fauziah Ishak C., McLaughlin M.J., \& Cozens G., (2004). Heavy metals in soils and crops in southeast Asia.1. Penisulasr Malaysia. Environ. Geochem. Health. 26(3), 343-357.

Zhao K., Liu X., Xu J., \& Selim H.M., (2010). Heavy metal contamination in a soil-rice system: Identification of spatial dependence in relation to soil properties of paddy fields. Journal of Hazardous Material. 181(1-3), 778-787. 